\title{
Sposoby radzenia sobie ze stresem i umiejscowienie poczucia kontroli u ofiar cyberprzemocy
}

\section{Coping with stress and locus of control in cybervictims}

\author{
Marcin Szulc $₫$ \\ Uniwersytet Gdański, Zakład Psychologii Osobowości i Psychologii Sądowej, ul. Jana Bażyńskiego 4, 80-309 Gdańsk \\ University of Gdańsk, Department of Psychology of Personality and Forensic Psychology \\ $\triangle$ psyms@univ.gda.pl
}

\begin{abstract}
Introduction: Many health issues are connected with experiencing chronic stress. One of its sources can be cyberbullying, which appeared with the emergence of new media and the growing significance of digital social life. Research and observations indicate that bullying can seriously affect people's lives and can be a factor inducing suicidal thoughts. From the health point of view, it is important how a young person deals with the bullyingrelated stress and where their locus of control is.

The main aim of the research was to ascertain how cybervictims deal with bullying-related stress.

Materials and methods: A group of 30 students were identified by school teachers from 3 junior high schools in the Pomeranian

ABSTRAKT

Wstęp: Wiele problemów zdrowotnych wiąże się z doświadczaniem przewlekłego stresu. Jednym z czynników zagrażających optymalnemu funkcjonowaniu człowieka i jego zdrowiu jest cyberprzemoc, która pojawiła się wraz z powstaniem nowych mediów. Wzrost tzw. zachowań przemocowych w internecie jest konsekwencją intensyfikacji cyfrowego życia towarzyskiego. Badania i obserwacje wskazują, że przemoc rówieśnicza (bullying) dezorganizuje życie i jest bardzo poważnym czynnikiem ryzyka wystąpienia myśli i prób samobójczych. Z punktu widzenia zdrowia i pozytywnego rozwoju istotny jest sposób, w jaki człowiek radzi sobie ze stresem oraz umiejscawia poczucie kontroli nad zdarzeniami. Według Kofty ważnym elementem w radzeniu sobie z trudną sytuacją jest poczucie bezpieczeństwa. Celem badania było ustalenie, w jaki sposób radzą sobie ze stresem i jaki poziom poczucia umiejscowienia kontroli przejawiają ofiary cyberprzemocy.
\end{abstract}

region in Poland as victims of cyberbullying. The control group consisted of 30 students, also from junior high schools. They were asked to fill in a Coping Inventory for Stressful Situations (CISS) and KBPK - Questionnaire for Locus of Control Study. Results: Cyberbullying victims differed significantly from the control group in their styles of coping with stress and in their locus of control.

Conclusion: The results confirmed the belief that bullied students often chose a stress management style focused on emotions. Their external locus of control made it difficult for them to find effective help and reinforced the sense of no impact on events. Keywords: stress coping; locus of control; cyberbullying; cybervictims.
Materiały i metody: Korzystając z Kwestionariusza Radzenia Sobie ze Stresem (CISS) oraz Kwestionariusza Badania Poczucia Kontroli (KBPK), zbadano grupę 30 osób zidentyfikowanych przez pedagogów szkolnych z 3 gimnazjów w obrębie województwa pomorskiego jako ofiary cyberprzemocy oraz 30 osób z grupy kontrolnej, również uczniów gimnazjów.

Wyniki: Ofiary cyberprzemocy różnią się istotnie w zakresie stylów radzenia sobie ze stresem i umiejscowienia poczucia kontroli od osób z grupy kontrolnej.

Wnioski: Osoby z grupy kryterialnej najczęściej wybierają styl radzenia sobie ze stresem skoncentrowany na emocjach i cechują się zewnętrznym nasileniem poczucia kontroli, co utrudnia poszukiwanie skutecznej pomocy oraz utwierdza je w poczuciu braku wpływu na wydarzenia.

Słowa kluczowe: radzenie sobie ze stresem; poczucie umiejscowienia kontroli; cyberprzemoc; cyberofiary.

\section{WSTĘP}

Przemoc rówieśnicza (bullying, mobbing) definiowana jest na ogół jako ukierunkowane zachowanie polegające na powtarzających się, wielokrotnych atakach, których celem jest zaszkodzenie osobie. Istotne jest to, że ofiara nie jest w stanie obronić się sama albo możliwości przeciwstawienia się sprawcom są znikome [1]. Zdaniem Pyżalskiego [2], aby wystąpił bullying, muszą być spełnione trzy warunki w tym samym czasie:

- intencjonalność - celem wrogich działań sprawcy lub sprawców jest sprawienie ofierze przykrości lub zranienie jej (nie tylko fizycznie);

- powtarzalność - agresywne działania sprawców mają charakter długotrwały, powtarzają się wobec tej samej ofiary (działania nie są incydentalne);

- nierównowaga sił - sprawcy są silniejsi od ofiary (także w mniemaniu ofiary), np. silniejsi fizycznie, w przewadze liczebnej, są bardziej wygadani, mogą szybciej myśleć 
od ofiary i mieć zawsze gotową odpowiedź w czasie publicznej wymiany zdań [2].

Bullying to działanie oparte na nierównowadze sił, w którym sprawca nadużywa własnej mocy przy równoczesnym pozbawieniu jej ofiary [3, 4]. Przestrzeń oddziaływania przemocy rówieśniczej nie ogranicza się tylko do terenu szkoły czy podwórka, rozpościera się również w tzw. nowych mediach, czyli w przestrzeni zdigitalizowanej. Cyberprzemoc definiuje się jako nową, celową formę powtarzającej się agresji z użyciem technologii informacyjnych i komunikacyjnych wobec osoby lub grupy osób, które nie mają możliwości obrony [5, 6, 7, 8, 9, $10,11]$. Choć definicja jest powszechnie stosowana i wydaje się wypełniać znaczenie pojęcia cyberprzemocy, to niektóre jej aspekty są przedmiotem dyskusji. Na przykład w przemocy cyfrowej nie jest konieczne stwierdzenie braku równowagi fizycznej pomiędzy sprawcą i ofiarą. Bywa, że sprawca jest słabszy pod tym względem od ofiary. Podobnie dyskusyjna jest kwestia wielokrotności ataków, które cechują bezpośrednią przemoc. Pojedynczy atak w sieci może samoistnie wywołać efekt „śnieżnej kuli”, nad którym sprawca traci kontrolę i ogólnie przestaje panować nad sytuacją. Autor obraźliwego memu z udziałem ofiary może zamieścić go w sieci tylko raz, reszty dokonają inni użytkownicy, komentując i udostępniając materiał dalej [4]. Zakresu stosowania pojęcia nie należy zawężać tylko do przestrzeni w internecie, lecz także do przemocy z użyciem telefonów komórkowych, bowiem komunikaty o charakterze przemocowym pojawiają się często, wysyłane jako wiadomości SMS czy MMS. Zjawisko cyberprzemocy jest szczególnie uciążliwe dla ofiar ze względu na poczucie anonimowości sprawcy, łatwość rozprzestrzeniania kompromitujących materiałów i trudność ich usunięcia. W odróżnieniu od tradycyjnych form przemocy adresat narażony jest na stałe wznowy (sieć w odróżnieniu od szkoły działa całą dobę), co prowadzi do rozległych konsekwencji psychicznych i głębokiego poczucia krzywdy $[12,13]$. Nie każde doświadczenie przemocy (np. hejtu) czyni z uczestnika ofiarę cyberprzemocy. Reakcja zależy od oceny samego odbiorcy, jego lęku i poczucia zranienia. Niektórzy respondenci twierdzą, że tradycyjny bullying jest bardziej dokuczliwy niż cyfrowy [14]. Osoby postrzegające cyberbullying jako gorszy niż tradycyjna przemoc argumentowały, że najbardziej zagrażające w ich mniemaniu są anonimowość ataków i brak możliwości kontroli sytuacji [4]. Istnieje także pogląd, że cyberprzemoc jest znacznie bardziej niebezpieczna niż przemoc bezpośrednia: (...) agresja relacyjna, która atakuje ofiarę $w$ sieci i prowadzi do zniesławienia i zniszczenia reputacji, jest poważniejszym problemem niż werbalne i seksualne nękanie [15]. Poziom wiktymizacji jest także różny w zależności od rodzaju ataku. W ocenie ofiar cyberprzemocy poczucie krzywdy (bezradności, depresyjności, bezbronności, martwienia się) jest silniejsze w przypadku wiadomości zamieszczanych w sieci niż poprzez zastraszanie bezpośrednie za pomocą wiadomości tekstowych (SMS, e-mail). Podobnie publikowanie ośmieszających zdjęć i nagrań wideo w perspektywie ofiar ma bardziej negatywny wpływ niż np. wysyłanie krzywdzących wiadomości tekstowych $[6,16]$. Wielu badaczy wskazuje, że zjawisko cyberprzemocy jest niedoszacowane $[17,18]$.
Z całą pewnością nie jest marginalne, gdyż ok. 1/5 uczniów szkół średnich w USA pada ofiarą cyberprzemocy, zaś w Polsce co 5. nastolatek doświadczył poniżania, ośmieszania i upokarzania w sieci [19, 20]. Aż 19\% młodzieży w wieku 10-18 lat było albo jest sprawcą lub ofiarą cyberbullyingu [21]. Ustalono także, że $25 \%$ sprawców cyberprzemocy i ich ofiar pochodziło z tej samej szkoły, a zatem bardziej prawdopodobne jest, że do spotkań dochodziło także twarzą w twarz [22]. Okazuje się także, że chłopcy częściej są zarówno sprawcami, jak i ofiarami przemocy, ale znacznie częściej przemocy seksualnej w internecie (np. podwójnych standardów dotyczących zachowań seksualnych) doświadczają dziewczęta [23, 24] oraz mniejszości seksualne (np. osoby nieheteronormatywne) [25]. Sprawcy stosują różnorodne formy cyberprzemocy, jak bezpośrednie groźby (wysyłanie pogróżek), flaming (flame war - wojna na obelgi), kradzież tożsamości (tworzenie fałszywych profili i stron internetowych przypisanych do ofiary), izolowanie (uniemożliwianie lub utrudnianie kontaktu w grupie społecznościowej w sieci), cyberstalking (nękanie, śledzenie), upokarzanie (tworzenie grafik, memów, fotomontaży, wysyłanie, powielanie, zamieszczanie filmów, w których ofiara wykonuje krępujące dla niej czynności, rozpowszechnianie pomówień (wysyłanie fałszywych informacji do moderatorów administratorów stron w celu usunięcia czyjegoś konta lub zablokowania strony, upublicznianie tajemnic ofiary, a także cyberbaiting, czyli prowokowanie ofiar (najczęściej nauczycieli) do zachowań nieprofesjonalnych, nagrywanie ich i zamieszczanie w sieci w celu wywołania zakłopotania ofiary [26].

Cyberbullying określa się jako zjawisko jednoznacznie negatywne. Konsekwencje psychologiczne cyberprzemocy są bardzo poważne i dobrze udokumentowane. Dramatyczne wydarzenia w ciągu ostatniego dziesięciolecia potwierdzają istnienie tego problemu także w Polsce. Ofiary doświadczają odrzucenia przez grupę, co skutkuje poczuciem samotności, niską samooceną i depresją. Skutki cyberprzemocy mogą utrzymywać się także w dorosłym życiu. Wiele badań potwierdza, że ofiary cyberprzemocy w wieku szkolnym cierpią na lęki, fobie, paranoje, w wyniku stresu doświadczają licznych objawów psychosomatycznych, takich jak bóle głowy, bóle brzucha i bezsenność, a także przejawiają zaburzenia zachowania i częściej sięgają po alkohol. Najpoważniejszym skutkiem jest jednak depresja, która może prowadzić do prób samobójczych [27, 28, 29, 30, 31, 32, 33]. Doznawanie cyberprzemocy jest trudną sytuacją dla ofiary, silnie stresującą, stanowi duże wymaganie, któremu ofiara musi sprostać. Brak możliwości identyfikowania źródła i przyczyny zagrożenia skutkuje poczuciem utraty kontroli.

Z punktu widzenia zdrowia człowieka długotrwałe oddziaływanie sytuacji stresowych jest szkodliwe. Może prowadzić do stanów lękowych, nerwic, zachowań agresywnych, objawów fizjologicznych, np. wzrostu ciśnienia krwi, zaburzeń rytmu serca, spadku poziomu wapnia i magnezu [34]. To od predyspozycji człowieka zależy, czy stres będzie oddziaływał destrukcyjnie (distres) czy pozytywnie (eustres) [34, 35]. Styl radzenia sobie ze stresem określa się jako względnie stałą tendencję do stosowania w różnych sytuacjach specyficznych 
dla jednostki sposobów radzenia sobie mających na celu usunięcie lub redukcję stanu stresu [36]. Endler i Parker [37, 38] zaproponowali model uwzględniający trzy style radzenia sobie ze stresem, będące konkluzją dobrze udokumentowanych badań własnych: styl skoncentrowany na zadaniu (SSZ), styl skoncentrowany na emocjach (SSE) oraz styl skoncentrowany na unikaniu (SSU). Styl skoncentrowany na zadaniu polega na podjęciu przez jednostkę wysiłku, aby poradzić sobie z problemem poprzez zmianę sytuacji lub przekształcenia poznawcze. Styl skoncentrowany na emocjach cechuje te osoby, które w sytuacjach stresowych przejawiają skłonność do koncentracji na własnych (głównie negatywnych) emocjach, takich jak gniew czy poczucie winy. Cechą charakterystyczną tego stylu jest myślenie życzeniowe i fantazjowanie, dzięki którym osoby zmniejszają w ten sposób napięcie emocjonalne związane z sytuacją. Styl skoncentrowany na unikaniu charakteryzuje osoby, które w sytuacjach stresowych mają tendencje do unikania przeżywania i doświadczania ich poprzez angażowanie się w czynności zastępcze. Styl ten może przyjmować dwie formy: angażowanie się w czynności zastępcze (ACZ), np. oglądanie TV, sen, objadanie lub poszukiwania kontaktów towarzyskich (PKT). Stylem najbardziej efektywnym, a zatem pożądany jest SSZ.

Poczucie kontroli, które można traktować jako wymiar osobowości, określa się jako: (...) zgeneralizowany sposób ujmowania przez jednostkę zwiq̨zków przyczynowych pomiędzy jej własnymi zachowaniami i ich skutkami, czyli wzmocnieniem [39]. W sensie subiektywnym jest to świadoma aktywność ukierunkowana na osiągnięcie określonego celu, czyli skutku [40]. Poczucie kontroli manifestuje się u jednostek w przekonaniu, że istnieje związek pomiędzy ich działaniem a efektami tego działania zgodnymi z oczekiwaniami, gdy posiadają swobodę wyboru celu i metod jego osiągnięcia [41]. Przekonanie, że zarówno pozytywne, jak i negatywne wydarzenia, których jednostka doświadcza w życiu, są konsekwencją własnych działań i podlegają osobistej kontroli, określa się jako wewnętrzne umiejscowienie poczucia kontroli (internal LOC). Natomiast zewnętrzne umiejscowienie poczucia kontroli (external LOC) oznacza odbiór pozytywnych lub negatywnych wydarzeń jako niezwiązanych z własnym zachowaniem, a tym samym znajdujących się w gestii losu lub szczęścia, czyli poza osobistą kontrolą człowieka [42]. Osoby, które cechuje internal LOC, są lepiej przystosowane społecznie i emocjonalnie, prezentują wyższą samoocenę, motywację osiągnięć, niezależność w działaniu, mają lepsze wyniki w nauce i żyją zdrowiej, efektywnie korzystają z doświadczeń, twierdzą, iż skutki działań zależą od nich samych, podczas gdy osoby o external LOC uważają dokładnie odwrotnie, czyli że zewnętrzne umiejscowienie kontroli wiąże się z brakiem zaufania do własnych możliwości kontroli sytuacji i utratą poczucia sensu angażowania się w działania i może być przejawem mechanizmu obronnego. Badania potwierdzają, że rodzaj poczucia kontroli wiąże się z dobrym samopoczuciem (wellbeing) [42, 43]. Jak z tego wynika, bardziej pożądana jest zatem wewnętrzna lokalizacja poczucia kontroli. Gdy jednostka nie chce ponosić odpowiedzialności za własne działania, zwłaszcza te, które kończą się porażką, wówczas w celu ochrony obrazu własnego „ja” lokalizuje przyczyny zdarzeń w świecie zewnętrznym [44]. Poczucie umiejscowienia kontroli wiąże się z zachowaniami zdrowotnymi młodzieży, wpływa na podjęcie decyzji o stosowaniu bądź rezygnacji z używek. Currie i wsp. dostrzegli, że external LOC wiązało się z częstszym używaniem marihuany [45]. Podobne obserwacje dotyczyły używania wyrobów tytoniowych [46]. Jak dowiedziono, zewnątrzsterowność wiąże się z zachowaniami antyzdrowotnymi [47]. Chaim zauważa, że z wewnętrznym poczuciem kontroli wiąże się potrzeba refleksji nad własnymi przeżyciami, emocjonalne zrównoważenie, niższy niepokój, intelektualizacja oraz większa potrzeba własnych osiągnięć [39]. Wewnętrzny LOC jest związany z większymi sukcesami edukacyjnymi, zawodowymi oraz lepszym zdrowiem i samopoczuciem psychicznym. Ponadto zaznacza się u tych osób tendencja do przypisywania sobie odpowiedzialności za sukcesy, przy równoczesnym unikaniu odpowiedzialności za porażki [48]. Wewnętrzne umiejscowienie poczucia kontroli wiąże się ze stosowaniem skuteczniejszych strategii radzenia sobie ze stresem, a także poprawia ogólną jakość życia chorych [42].

Celem badania było ustalenie, $\mathrm{w}$ jaki sposób ofiary cyberprzemocy radzą sobie ze stresem i jakie jest ich umiejscowienie poczucia kontroli. Przyjęto, że zmienną niezależną jest doświadczana przez ofiary cyberprzemoc, zaś zmienną zależną umiejscowienie poczucia kontroli i styl radzenia sobie ze stresem. Postawiono dwie hipotezy:

H1. Ofiary cyberprzemocy częściej niż osoby z grupy kontrolnej (dobór wiązany) prezentują styl radzenia sobie ze stresem skoncentrowanym na emocjach.

H2. Ofiary cyberprzemocy częściej niż osoby z grupy kontrolnej prezentują zewnętrze umiejscowienie poczucie kontroli.

\section{MATERIAtY I METODY}

Badaniami z zastosowaniem Kwestionariusza do Badania Poczucia Kontroli (KBPK) autorstwa Krasowicz i Kurzyp-Wojnarskiej oraz Kwestionariusza Radzenia Sobie w Sytuacjach Stresowych Endlera i Parkera (Coping Inventoiy for Stressful Situations - CISS) w polskiej adaptacji objęto grupę 60 osób, uczniów gimnazjum $[48,49,50]$. Grupa kryterialna składała się z 30 osób (9 chłopców, 21 dziewcząt) w wieku 13-16 lat, zidentyfikowanych przez pedagogów szkolnych jako ofiary cyberprzemocy z trzech gimnazjów w województwie pomorskim (gimnazjum $A=9$ osób, gimnazjum $B=10$ osób, gimnazjum $\mathrm{C}=11$ osób) ze zbliżonych wielkością aglomeracji spoza Trójmiasta. Do grupy kontrolnej zakwalifikowano osoby wykorzystując regułę doboru wiązanego; przyjęto podobieństwa w zakresie wieku, płci i średniej ocen.

Ofiary najczęściej ujawniały problem rodzicom i pedagogom szkolnym z powodu własnego cierpienia albo dlatego, że nie były już w stanie dłużej utrzymywać tego w tajemnicy. Dzieci i młodzież doświadczające przemocy niechętnie ujawniają sytuację, w jakiej się znalazły, z powodu odczuwanej winy i wstydu, że nie są w stanie same sobie z nią poradzić. Są także 
przekonane, że rodzice nie powstrzymają ataków, ale również obawiają się konsekwencji w postaci utraty lub ograniczenia dostępu do internetu przez opiekunów [51]. W kilku przypadkach rodzice dostrzegli niepokojące objawy u dziecka i zaangażowali się w wyjaśnienie przyczyn wbrew woli ofiary. Ofiary doświadczyły przemocy niejednorazowo, najczęściej w postaci rozpowszechniania nieprawdziwych, krzywdzących, ośmieszających informacji, memów naruszających godność ucznia oraz fotomontaży z ich udziałem (w 4 przypadkach były to anonimowe maile z pogróżkami i obelgami). Do momentu ujawnienia cyfrowe dręczenie trwało od kilku tygodni do 6 miesięcy. Szkoły podjęły działania wobec sprawców i ofiar (wsparcie psychologiczno-pedagogiczne). Wszystkie 3 szkoły cieszą się dobrą opinią w swoim mieście. Placówki podjęły działania wobec sprawców, świadków i ofiar oraz wdrożyły programy przeciwdziałania zjawisku cyberprzemocy. Jedna trzecia opiekunów prawnych małoletnich zawiadomiła policję i większość sprawców wykryto. W związku z tym, że w polskim prawie formalnie nie istnieje taka kategoria prawna jak cyberprzemoc, wszczęto wobec sprawców postępowania cywilne lub karne z artykułów: o naruszeniu dóbr osobistych dziecka (art. 23 i 24 k.c.), o zniewadze (art. 216 k.k.), o zniesławieniu (art. 212 k.k.), o włamaniu (art. 267 i 268a k.k.), o groźbie (art. 190 i 191 k.k.), o nękaniu (art. 197 k.w.) oraz o wulgaryzmach w miejscu publicznym (141 k.w.) [52]. Badani wypełniali kwestionariusze mniej więcej miesiąc po ujawnieniu cyberprzemocy i podjęciu działań przez szkołę i rodziców. Ofiary najczęściej nie potrafiły zidentyfikować przyczyn oraz dokładnego momentu pojawienia się krzywdzących treści w sieci.

Kwestionariusz do Badania Poczucia Kontroli posiada dwie wersje (dla dziewcząt i chłopców) różniące się jedynie formą gramatyczną i składa się z 46 pytań z wymuszonym wyborem, z czego 36 to pytania diagnostyczne dotyczące sytuacji porażek (skala $\mathrm{P}$ - poczucia umiejscowienia porażek) oraz sukcesów (skala S - poczucia umiejscowienia sukcesów), a pozostałe 10 to pytania buforowe. Im niższy uzyskany wynik, tym bardziej zewnętrze umiejscowienia poczucia kontroli [51].

Kwestionariusz Radzenia Sobie w Sytuacjach Stresowych Endlera i Parkera składa się z 48 stwierdzeń opisujących zachowanie ludzi w sytuacjach stresowych. Do oceny własnych zachowań zastosowano 5-stopniową skalę Likerta określającą częstotliwość, z jaką dana aktywność jest podejmowana w sytuacji stresowej [53]. Kwestionariusz zawiera 3 główne skale: SSZ, SSE i SSU. Ostatnia skala zawiera dwie podskale mierzące stopień ACZ, np. oglądanie telewizji, objadanie się, sen oraz PKT.

\section{WYNIKI}

W ramach przeprowadzonego badania weryfikowano hipotezę na temat różnic w zakresie średnich pomiarów stylów radzenia sobie ze stresem i poczuciem kontroli dla dwóch prób niezależnych grupy ofiar cyberprzemocy oraz grupy kontrolnej. Weryfikacja rozkładu zabranych wyników wykazała normalność, co dało podstawy do zastosowania testu t-Studenta dla
TABELA 1. Porównanie średnich dla prób niezależnych z wykorzystaniem testu t-Studenta dla wyników z CISS

\begin{tabular}{|c|c|c|c|c|c|c|}
\hline & Grupa & $\mathrm{n}$ & Średnia & SD & $t$ & $p$ \\
\hline \multirow{2}{*}{ SSZ } & ofiary & 30 & 17,83 & 1,510 & \multirow{2}{*}{$-122,029$} & \multirow{2}{*}{0,001} \\
\hline & kontrolna & 30 & 78,87 & 2,285 & & \\
\hline \multirow{2}{*}{ SSE } & ofiary & 30 & 75,37 & 2,059 & \multirow{2}{*}{79,261} & \multirow{2}{*}{0,001} \\
\hline & kontrolna & 30 & 18,37 & 3,358 & & \\
\hline \multirow{2}{*}{ SSU } & ofiary & 30 & 36,60 & 3,318 & \multirow{2}{*}{$-28,954$} & \multirow{2}{*}{0,001} \\
\hline & kontrolna & 30 & 62,07 & 3,493 & & \\
\hline \multirow{2}{*}{$A C Z$} & ofiary & 30 & 23,97 & 2,785 & \multirow{2}{*}{$-4,070$} & \multirow{2}{*}{0,001} \\
\hline & kontrolna & 30 & 27,10 & 3,166 & & \\
\hline \multirow{2}{*}{ PKT } & ofiary & 30 & 6,53 & 2,030 & \multirow{2}{*}{$-43,099$} & \multirow{2}{*}{0,001} \\
\hline & kontrolna & 30 & 24,17 & 0,950 & & \\
\hline
\end{tabular}

SSZ - styl skoncentrowany na zadaniu; SSE - styl skoncentrowany na emocjach; SSU - styl skoncentrowany na unikaniu; ACZ - angażowanie się w czynności zastępcze; PKT - poszukiwanie kontaktów towarzyskich

TABELA 2. Porównanie średnich dla prób niezależnych z wykorzystaniem testu t-Studenta dla wyników z KBPK

\begin{tabular}{|c|c|c|c|c|c|c|}
\hline & Grupa & $n$ & Średnia & SD & $\mathrm{t}$ & $p$ \\
\hline \multirow{2}{*}{ Skala S } & ofiary & 30 & 2,80 & 1,901 & \multirow{2}{*}{$-20,282$} & \multirow{2}{*}{0,001} \\
\hline & kontrolna & 30 & 15,00 & 2,691 & & \\
\hline \multirow{2}{*}{ Skala P } & ofiary & 30 & 2,43 & 2,029 & \multirow{2}{*}{$-17,732$} & \multirow{2}{*}{0,001} \\
\hline & kontrolna & 30 & 14,50 & 3,127 & & \\
\hline \multirow{2}{*}{$\begin{array}{l}\text { LOC } \\
\text { uogólniony } \\
(\mathrm{S}+\mathrm{P})\end{array}$} & ofiary & 30 & 5,23 & 5,23 & \multirow[b]{2}{*}{$-24,625$} & \multirow[b]{2}{*}{0,00} \\
\hline & kontrolna & 30 & 29,50 & 29,50 & & \\
\hline
\end{tabular}

Skala S - skala sukcesów; skala P - skala porażek; LOC uogólniony - wynik ogólny (suma S + P) umiejscowienia poczucia kontroli

prób niezależnych. Obliczenia przeprowadzono w programie SPSS, przyjmując poziom istotności $\mathrm{p}=0,05$ (tab. 1).

Ofiary cyberprzemocy uzyskały istotnie niższe wyniki niż grupa kontrolna w skali stylu skoncentrowanego na zadaniu, stylu skoncentrowanego na unikaniu oraz w zakresie podskal SSU, czyli skali ASZ i PKT. Istotnie wyższy wynik uzyskały tylko w zakresie skali SSE. W przypadku umiejscowienia poczucia kontroli obydwie grupy również różnią się istotnie w zakresie wszystkich skal (tab. 2).

Ofiary cyberprzemocy w porównaniu z grupą kontrolną prezentują ekstremalnie zewnętrzne uogólnione umiejscowienia poczucia kontroli, a różnice dotyczą zarówno interpretacji porażek, jak i sukcesów. Te duże różnice pomiędzy grupami występują mimo badania osób w okresie dorastania. Zazwyczaj w tym czasie pojawia się wysoki samokrytycyzm polegający na silnej internalizacji porażek i niskiej internalizacji sukcesów [49, 50].

\section{DYSKUSJA}

Przeprowadzone przez autora analizy potwierdzają wyniki badań, które uzyskali Völlink i wsp. na grupie 88 ofiar cyberprzemocy [54]. Badani w nich uczniowie doświadczający 
cyberprzemocy, częściej niż ofiary będące równocześnie sprawcami, wykorzystywali strategie radzenia sobie ze stresem skoncentrowane na emocjach. Zazwyczaj radzili sobie z problemem poprzez emocjonalne wypowiedzi i unikanie rówieśników. U ofiar cyberprzemocy dominuje SSE, co oznacza, że nie radzą sobie z doświadczaną przemocą, wykazują większą niż grupa kontrolna tendencję do koncentrowania się na własnych przeżyciach emocjonalnych takich jak złość, poczucie winy czy napięcie. Przejawiają także tendencję do myślenia życzeniowego i fantazjowania, np. marzą, by udało się cofnąć czas do momentu sprzed pojawienia się krzywdzących treści. Często dominuje uczucie lęku, smutku i osamotnienia w grupie, które bywa zauważalnym sygnałem dla otoczenia, że dziecko może być ofiarą rówieśniczej przemocy [55]. Osoby z grupy kontrolnej częściej prezentują SSZ oraz SSU. Ofiary cyberprzemocy istotnie rzadziej niż osoby z grupy kontrolnej angażują się w czynności zastępcze i poszukują kontaktów towarzyskich, co również potwierdzono w wynikach uzyskanych przez Völlink i wsp. [54]. Dzieje się tak w związku z odczuwanym poczuciem wstydu i zażenowania, które są tym większe, im bardziej ofiara przekonana jest o dotarciu krępujących dla niej informacji do większej publiczności [4, 22].

Poczucie kontroli odgrywa kluczową rolę w sterowaniu zachowaniem. Osoby cechujące się zewnętrznym umiejscowieniem poczucia kontroli są gorzej przystosowane emocjonalnie, przejawiają niższą samoocenę i samoakceptację, wyższy poziom niepokoju, zarówno jawny, jak i ukryty, na który składają się: brak integracji, słabość ego, poczucie winy i podwyższone napięcie wewnętrzne. Najczęściej stosują mechanizmy obronne jak zwątpienie i projekcja, dzięki którym radzą sobie z poczuciem zagrożenia [39]. Osoby o zewnętrznym LOC nie podejmują prób wywarcia wpływu na zewnętrzną sytuację, gdyż dominuje u nich postawa fatalistyczna [48], co wielokrotnie dało się zauważyć w wypowiedziach niektórych badanych zaraz po ujawnieniu problemu, np. „nie mam na to wpływu”, „tak już teraz będzie”, „nie chce mi się żyć”, „nic się nie zmieni”, „jak nie ci, to inni”, „, to się nigdy nie skończy”, „,boję się włączyć internet". Najbardziej dojmujące dla ofiar było poczucie wstydu i zranienia związane ze świadomością istnienia publiczności, która w tym uczestniczy. Paradoksalnie ta duża widownia może też sprzyjać ujawnieniu problemu, a tym samym udzieleniu pomocy, gdyż im większe jest zorientowanie w tym, co się dzieje, tym łatwiej informacja może trafić do osób dorosłych. Właśnie w ten sposób sytuacja większości badanych cyberofiar została ujawniona. W późniejszym czasie (blisko miesiąc po zakończeniu badań) wsparcie dorosłych (zwłaszcza zdecydowana postawa rodziców i pedagogów) złagodziły ton wypowiedzi badanych osób: „w sumie dobrze, że to wyszło na jaw”, „Boże, jak ja się wtedy okropnie czułam”, , ,jest już lepiej”, „mniej się stresuję”, „,mam nadzieję, że to nigdy nie wróci”, „na pewno będę ostrożniejsza na Fejsie”, „nie obchodzi mnie już, co myślą inni". Wydaje się więc, że osoby, którym udzielono wsparcia, zmieniły percepcję traumatycznego doświadczenia. Warto byłoby zbadać ponownie zarówno styl radzenia sobie ze stresem, jak i umiejscowienie poczucia kontroli, aby ustalić, czy uległy one rzeczywistej i trwałej zmianie.
Szereg badań dostarcza informacji o tym, że ważną rolę w procesie przeciwdziałania agresji rówieśniczej odgrywają jej świadkowie $[56,57,58,59]$. Rozumienie ich roli niesie za sobą konieczność modyfikacji perspektywy tego zjawiska od diadycznej - sprawca-ofiara, ku triadycznej - sprawca-ofiaraświadek [54]. Znacząca większość aktów agresji rówieśniczej (prawie 90\%) jest realizowana w obecności audytorium [60]. Sprawca intencjonalnie przygotowuje kompromitujące ofiarę materiały, zaś świadkowie je powielają i rozpowszechniają. Zachowanie świadków cyberprzemocy nigdy nie jest w pełni neutralne [61]. Obecność świadków może pełnić rolę terapeutyczną, gdy stają w obronie ofiary [56], ale też toksyczną, gdy wzmacniają działania sprawcy $[62,63,64]$. Nieprzesyłanie lub niepublikowanie, a zwłaszcza usuwanie kompromitujących materiałów jest świadectwem rozumienia, w jaki sposób funkcjonują informacje w sieci. Ta wiedza ma ogromny wpływ na powtarzalność aktów cyberprzemocy i może pomóc przeciwstawiać się uczestnictwu w tym procederze [13]. Wynika z tego, że tylko czynnik ludzki może ograniczyć cyberprzemoc.

\section{WNIOSKI}

Istotnym problemem wydaje się zdolność do radzenia sobie z taką sytuacją, która jest konsekwencją interpretacji zdarzenia. Percepcja zagrożenia zależy od sytuacji, w której znalazła się osoba, ale również od tego, w jaki sposób organizuje i reprezentuje wiedzę o świecie [65]. Heszen-Niejodek podkreśla, że o uznaniu relacji za stresową rozstrzyga subiektywna ocena jej znaczenia przez osobę, która w niej uczestniczy, a nie właściwości obiektywne [66]. Czeskie badania nad skutecznością radzenia sobie z cyberprzemocą przeprowadzone na grupie 2092 dzieci w wieku 12-18 lat, doświadczających zarówno ciężkiej wiktymizacji, jak i łagodniejszych form cyberprzemocy, nie ujawniły określonej strategii radzenia sobie z problemem, a większość z tych, które zastosowano, okazała się nieskuteczna. Metodą efektywną stało się rozważanie przez ofiary zastosowania rozwiązań technicznych, takich jak blokowanie kontaktów na portalach społecznościowych, oraz rozwiązań psychologicznych, np. poszukiwanie wsparcia albo ignorowanie krzywdzących treści w sieci [59]. Cassidy i wsp. zapytali kanadyjskich uczniów o to, do kogo zwróciliby się o pomoc, gdyby stali się ofiarami cyberbullyingu. Aż 74\% odpowiedziało, że byłby to przyjaciel, $57 \%$ poinformowałoby rodzica, a $47 \%$ personel szkoły [25]. Autorzy raportu zwracają jednak uwagę, że ten optymistyczny wynik ma raczej charakter deklaratywny, gdyż osoby znajdujące się w sytuacji zagrożenia często nie potrafią racjonalnie i skutecznie zareagować. Wydaje się zatem, że skupienie na przeżywaniu własnych emocji i zewnętrzne umiejscowienie poczucia kontroli u ofiar cyberprzemocy to nie tylko wymiary psychologiczne odpowiedzialne za zły stan emocjonalny, ale również za poczucie bezradności, które utrudnia poszukiwanie konstruktywnej pomocy, a przede wszystkim przerwanie procesu krzywdzenia. Należy podkreślić, że kluczowymi moderatorami w procesie agresji rówieśniczej są świadkowie [56, 59, 67]. Mogą pełnić ważną rolę, tak 
w rozprzestrzenianiu, jak i hamowaniu rozpowszechniania krzywdzących treści, poprzez rozsyłanie lub powstrzymanie się przed udostępnianiem i publikowaniem kompromitujących materiałów. Mogą je nawet usuwać [13]. Stanowią również najbardziej oczywisty element systemu wsparcia rówieśniczego. Ofiary przemocy postrzegają działania pomocowe rówieśników jako skuteczniejsze niż działania wspierające ze strony osób dorosłych, warto zatem wykorzystać ten potencjał [68].

Przedstawione badania, ze względu na niewielką grupę, powinny być kontynuowane na większej populacji. Interesujące wydaje się sprawdzenie różnic płciowych w reagowaniu na cyberprzemoc oraz poszukiwanie odpowiedzi na następujące pytania: Czy ofiary cyberprzemocy różnią się w innych zmiennych psychologicznych od grupy kontrolnej? Czy zmienił się ich stosunek do nowych mediów? Czy to trudne doświadczenie przyniosło jakieś pozytywne skutki, np. poznawcze, dzięki którym zwiększyła się ich wiedza o social mediach i umiejętności komunikacyjne? Czy doświadczenie przemocy wirtualnej wywiera podobnie długotrwały wpływ na jakość życia, co tradycyjny bullying?

\section{PIŚMIENNICTWO}

1. Olweus D. Sweden. In: Smith PK, Morita Y, Junger-Tas J, Olweus D, Catalano R, Slee P, editors. The nature of school bullying: A cross-national perspective. Sussex: Routledge; 1999. p. 7-27.

2. Pyżalski J. Bullying (mobbing) jako specyficzny typ agresji rówieśniczej. In: Rokicka B, editor. Poradnik pedagoga szkolnego. Gimnazjum i szkoła ponadgimnazjalna. Warszawa: Dr Josef Raabe. Spółka Wydawnicza; 2009.

3. Rigby K. New perspectives on bullying. London: Jessica Kingsley Publishers; 2002.

4. Slonje R, Smith PK, Frisén A. The nature of cyberbullying, and strategies for prevention. Comput Hum Behav 2013;29(1):26-32. doi: 10.1016/j. chb.2012.05.024.

5. Bendixen M, Endresen IM, Olweus D. Variety and frequency scales of antisocial involvement: Which one is better? Leg Criminol Psychol 2003;8(1):13550. doi: 10.1348/135532503322362924.

6. Smith PK, Mahdavi J, Carvalho M, Fisher S, Russell S, Tippett N. Cyberbullying: Its nature and impact in secondary school pupils. J Child Psychol Psychiatry 2008;49:376-85.

7. Breivik K, Olweus D. Children of Divorce in a Scandinavian Welfare State: Are They Less Affected Than US Children? Scand J Psychol 2006;47(1):61-74

8. Beran T, Li Q. The relationship between cyberbullying and school bullying. J Student Wellbeing 2007;1(2):15-33.

9. Vandebosch H, Van Cleemput K. Defining cyberbullying: A qualitative research into the perceptions of youngsters. Cyberpsychol Behav 2008;11:499-503.

10. Şahin M, Aydin B, Sari SV. Cyberbullying, cybervictimization and psychological symptoms: A study in adolescents. Cukurova University Faculty Education J 2012;41(1):53-9.

11. Chisholm JF. Review of the status of cyberbullying and cyberbullying prevention. J Information Systems Education 2014;25(1):77-87.

12. Mishna F, Cook C, Saini M, Wu MJ, MacFadden R. Interventions for children, youth and parents to prevent and reduce cyberabuse. Oslo: Campbell Systematic Reviews; 2009.

13. Spears B, Slee P, Owens L, Johnson B. Behind the scenes and screens. Insight into the human dimension of covert and cyberbullying. Z Psychol/J Psychol 2009;217:189-96.

14. Ortega R, Elipe P, Mora-Merchan JA, Calmaestra J, Vega E. The emotional impact on victims of traditional bullying and cyberbullying: A study of Spanish adolescents. Z Psychol/J Psychol 2009;217:197-204.

15. Straude-Müller F, Hansen B, Voss M. How stressful is online victimization? Effects of victim's personality and properties of the incident. Eur J Dev Psychol 2012;9(2):260-74. doi: 10.1080/17405629.2011.643170.
16. Dehue F. Cyberbullying research: new perspectives and alternative methodologies. Introduction to the special issue. J Commun Appl Soc Psychol 2013;23(1):1-6. doi: 10.1002/casp.2139.

17. Dehue F, Bolman C, Vollink T. Cyberbullying: youngsters' experiences and parental perception. Cyberpsychol Behav 2008;11(2):217-23.

18. Kowalski RM, Limber SP. Electronic bullying among middle school students. J Adolesc Health 2007;41(6):S22-30.

19. Wright VH, Burnham JJ, Inman CT, Ogorchock HN. Cyberbullying: using virtual scenarios to educate and raise awareness. J Computing Teacher Education 2009;26(1):35-42.

20. Wojtasik Ł. Cyberprzemoc - charakterystyka zjawiska. In: Wojtasik $七$, editor. Jak reagować na cyberprzemoc. Poradnik dla szkół. 2nd ed. Warszawa: Fundacja Dajemy Dzieciom Siłę; 2008. p. 6-10.

21. Ybarra M, Mitchell K. Online aggressor/targets, aggressors, and targets: A comparison of associated outh characteristics. J Child Psychol Psychiatry 2004;45(7):1308-16.

22. Slonje R, Smith PK. Cyberbullying: Anotherma in type of bullying? Scand J Psychol 2008;49(2):147-54.

23. Solberg ME, Olweus D, Endresen I. Bullies and victimsat school: are they the same pupils? Br J Educ Psychol 2007;77(1):441-64.

24. Ringrose J, Gill R, Livingstone S, Harvey L. Qualitative study of children, young people and 'sexting'. NSPCC (National Society for the Prevention of Cruelty to Children); 2012. http://www.nspcc.org.uk/Inform/resourcesforprofessionals/sexualabuse/sexting-research-report_wdf89269.pdf (11.02.2013).

25. Cassidy W, Jackson M, Brown KN. Sticks and stones can break my bones, but how can pixels hurt me? Students' experiences with cyber-bullying. Sch Psychol Int 2009;30(4):383-402.

26. Willard NE. Cyberbullying and cyberthreats. Responding to the challenge of online social aggression, threats, and distress. Champaign, IL: Research Press; 2007.

27. Mitchell KJ, Ybarra M, Finkelhor D. The relative importance of online victimization in understanding depression, delinquency, and substance use. Child Maltreat 2007;12:314-24

28. Juvonen J, Gross FE. Extending the school grounds? Bullying experiences in cyberspace. J Sch Health 2008;78:496-505.

29. Gradinger P, Strohmeier D, Spiel C. Traditional bullying and cyberbullying: identification of risk groups for adjustment problems. Z Psychol/J Psychol 2009;217(4):205-13. doi: 10.1027/0044-3409.217.4.205.

30. Perren S, Dooley J, Shaw T, Cross D. Bullying in school and cyberspace: associations with depressive symptoms in Swiss and Australian adolescents. Child Adolesc Psychiatry Ment Health 2010;4:28-38. doi: 10.1186/17532000-4-28

31. Sourander A, Brunstein KAB, Ikomen M, Lindroos J, Luntamo T, Koskelainen $\mathrm{M}$, et al. Psychosocial risk factors associated with cyberbullying among adolescents. Arch Gen Psychiatry 2010;67:720-8.

32. Schenk AM, Fremouw WJ. Prevalence, psychological impact, and coping of cyberbully victims among college students. J School Violence 2012;11:2137. doi: 10.1080/15388220.2011.630310.

33. Hinduja S, Patchin JW. Bullying, cyberbullying, and suicide. Arch Suicide Res 2010;14(3):206-21.

34. Sygit-Kowalkowska E. Radzenie sobie ze stresem jako zachowanie zdrowotne człowieka - perspektywa psychologiczna. Hygeia Public Health 2014;49(2):202-8.

35. Huber L. Style adaptacyjne do sytuacji stresowych w różnych grupach wiekowych a choroby cywilizacyjne XXI wieku. Probl Hig Epidemiol 2010;91(2):268-75.

36. Strelau J, Jaworowska A, Wrześniewski K, Szczepaniak P. Kwestionariusz Radzenia Sobie w Sytuacjach Stresowych. Warszawa: Pracownia Testów Psychologicznych Polskiego Towarzystwa Psychologicznego; 2005.

37. Endler NS, Parker JDA. Multidimensional assessment of coping: A critical evaluation. J Pers Social Psychol 1990;58(5):844-54.

38. Endler NS, Parker JDA. Assessment of multidimensional coping: Task, emotion, and avoidance strategies. Psychol Assess 1994;6(1):50-60.

39. Chaim W. Umiejscowienie poczucia kontroli a nasilenie potrzeb, lęku i mechanizmów obronnych. Studia Philosophiae Christianae 1996;32(2):275-83

40. Gliszczyńska X. Poczucie sprawstwa. In: Gliszczyńska X, editor. Człowiek jako podmiot życia społecznego. Wrocław-Warszawa-Kraków-GdańskŁódź: Ossolineum; 1983. p. 133-66. 
41. Szmajke A. Dążenie do uzyskania poczucia kontroli nad zdarzeniami jako modyfikator sądów atrybucyjnych i spostrzegania osób. Prz Psychol 1989;32(1):155-83.

42. Cotlar Graffeo L, Lynette S. Relationship between locus of control and health-related variables. Education 2006;126(3):593-6.

43. April KA, Dharani B, Peters K. Impact of locus of control expectancy on level of well-being. Rev Eur Studies 2012;4(2):124-37. doi: 10.5539/ res.v4n2p124.

44. Doliński D. Orientacja defensywna. Warszawa: PAN; 1993.

45. Currie RF, Perlman D, Walker L. Marijuana use among Calgary youths as a function of sampling and locus of control. Br J Addict 1977;72:159-65.

46. Clarke JH, MacPherson BV, Holmes DR. Cigarette smoking and external locus of control among young adolescents. J Health Soc Behav 1982;23:253-9.

47. Strzelecki W, Cybulski M, Strzelecka M. Rola poczucia umiejscowienia kontroli w kształtowaniu wybranych zachowań zdrowotnych adolescentów. Now Lek 2009;78(1):18-22.

48. Krasowicz G, Kurzyp-Wojnarska A. Kwestionariusz do badania poczucia kontroli /KBPK/. Warszawa: Polskie Towarzystwo Psychologiczne. Wydział Psychologii Uniwersytetu Warszawskiego. Laboratorium Technik Diagnostycznych im. Bohdana Zawadzkiego; 1990.

49. Szczepaniak P, Strelau J, Wrześniewski K. Diagnoza stylów radzenia sobie ze stresem za pomocą polskiej wersji kwestionariusza CISS Endlera i Parkera. Prz Psychol 1996;39:187-210.

50. Wrześniewski K. Style a strategie radzenia sobie ze stresem. Problemy pomiaru. In: Heszen-Niejodek L, Ratajczak Z, editors. Człowiek w sytuacji stresu. Problemy teoretyczne i metodologiczne. Katowice: Wydawnictwo Uniwersytetu Śląskiego; 1996. p. 44-6.

51. Campfield DC. Cyber Bullying and victimization: psychosocial characteristics of bullies, victims, and bully/victims. University of Montana; 2008. http://scholarworks.umt.edu/cgi/viewcontent. cgi?article=1307\&context $=$ etd (12.08.2017).

52. Podlewska J. Odpowiedzialność prawna za cyberprzemoc w stosunku do nieletnich. Dziecko Krzywdzone: Cyberprzemoc 2009;8(1)26:1-10.

53. Jachnis A. Cechy temperamentalne a style radzenia sobie ze stresem. Studia Psychologica 2000;1(1):53-68.

54. Völlink T, Bolman CAW, Dehue F, Jacobs NCL. Coping with cyberbullying: differences between victims, bully-victims and children not involved in bullying. J Commun Appl Soc Psychol 2013;23:7-24.

55. Olweus D. Annotation: Bullying at school: Basic facts and effects of a school based intervention program. J Child Psychol Psychiatry 1994;35(7):1171-90.
56. Salmivalli C. Participant role approach to school bullying: Implications for intervention. J Adolesc 1999;22(4):453-9.

57. Fonagy P, Twemlow SW, Sacco FC, Gies ML, Hess D. Improving the social and intellectual climate in elementary schools by addressing bully-victim-bystander power struggles. In: Cohen J, editor. Caring classrooms/ intelligent schools: the social emotional education of young children 2001. New York: Teachers' College Press; 2001. p. 162-82.

58. Kraft EM, Wang J. An exploratory study of the cyberbullying and cyberstalking experiences and factors related to victimization of students at a public liberal arts college. Int J Technoethics 2010;1(4):74-91. doi: 10.4018/jte.2010100106.

59. Macháckova H, Cerna A, Sevcikova A, Dedkova L, Daneback K. Effectiveness of copingstrategies for victims of cyberbullying. Cyberpsychology. J Psychosocial Res Cyberspace 2013;7:3. doi: 10.5817/CP2013-3-5.

60. Salmivalli C. Bullying and the peer group: a review. Aggression Violent Behavior 2010;15:112-20.

61. Garandeau CF, Cillessen AHN. From indirect aggression to invisible aggression: A conceptual view on bullying and peer group manipulation. Aggression Violent Behavior 2006;11:612-25.

62. Craig WM, Pepler DJ. Observations of bullying and victimization in the school yard. Can J School Psychol 1997;13:41-50. doi: 10.1177/ 082957359801300205.

63. Craig WM, Pepler DJ, Atlas R. Observations of bullying in the playground and in the classroom. School Psychol Int 2000;21:22-36.

64. O'Connell P, Pepler D, Craig W. Peer involvement in bullying: Insights and challenges for intervention. J Adolesc 1999;22:437-52.

65. Lazarus RS, Folkman S. Transactional theory and research on emotions and coping. Eur J Personality 1987;1(3):141-69. doi: 10.1002/per. 2410010304

66. Heszen-Niejodek I. Teoria stresu psychologicznego i radzenia sobie. In: Strelau J, editor. Psychologia 2000. Podręcznik akademicki. T. 2. Gdańsk: Gdańskie Wydawnictwo Psychologiczne; 2000. p. 463-78.

67. Twemlow SW, Fonagy P, Sacco F, Gies M, Hess D. Improving the social and intellectual climate in elementary schools by addressing bully-victimbystander power struggles. In: Cohen J, editor. Caring classrooms/intelligent schools: the social emotional education of young children. New York: Teachers College Press, Columbia University; 2001.

68. Davis S, Nixon C. Preliminary results from the Youth Voice research project: Victimization and strategies 2010. http://www.youthvoiceproject. com (15.08.2017). 